\title{
Contribution of Rhizobium-Mycorrhiza-Merapi-indigenous Rhizobacteria Association on Growth and Yield of Three Cultivars Soybean Cultivated on Coastal Sandy Soil
}

\author{
DOI: 10.18196/pt.2017.066.7-14
}

\author{
Linda Kusumastuti*, Agung Astuti, Sarjiyah \\ Department of Agrotechnology, Faculty of Agriculture, Universitas Muhammadiyah Yogyakarta, \\ Jl. Lingkar Selatan, Kasihan, Bantul, Yogyakarta 55183, Indonesia Telp. 0274 387656, \\ ${ }^{*}$ Corresponding author, e-mail: lindakusuma22@gmail.com
}

\begin{abstract}
A study was conducted to examine the effect of inoculum association between Rhizobium sp., mycorrhizae and Merapi-indigenous Rhizobacteria on the growth and yield of 3 soybean cultivars, and to determine the best inoculum and cultivars for soybean cultivation on coastal sandy soil. The study was conducted in the Agro-biotechnology and Research Laboratory and experimental station of Faculty of Agriculture, Universitas Muhammadiyah Yogyakarta during the period of September 2015 to June 2016. Experiments were conducted by using coastal sandy soil as planting medium in polybags by employing $4 \times 3$ factorial experiments, arranged in completely randomised design, and placed under the field condition. The first factor used was inoculation treatment consisted of 4 combination of inoculums: (1)Rhizobium sp. - mycorrhizae, (2) Rhizobium sp. - Merapi-indigenous Rhizobacteria, (3) Rhizobium sp. - mycorrhizae - Merapi-indigenous Rhizobacteria, and (4) without inoculation. The second factor was soybean cultivars consisted of 3 varieties: (1) Grobogan, (2) Detam-1, and (3) Petek. Observation was carried out on nodulation, mycorrhizal effect, Rhizobacterial population dynamics, plant growth and yield. The results showed that Rhizobiumsp.-mycorrhizae inoculated on Petek increased root growth, leaf area and yield (5,97 tonnes/ha). Rhizobiumsp.-mycorrhizae inoculation only increased diameter of nodules. It was also observed that the best soybean cultivar for coastal sandy soil was Petek. Keywords: Soybean cultivars, Rhizobium sp., Mycorrhizae, Rhizobacteria indigenous of Merapi, Coastal sandy soil
\end{abstract}

\begin{abstract}
ABSTRAK
Tujuan penelitian adalah mengetahui pengaruh asosiasi inokulum pada pertumbuhan dan hasil 3 varietas kedelai dan menetapkan asosiasi inokulum dan varietas yang sesuai untuk pengembangan kedelai di lahan pasir pantai. Penelitian dilaksanakan di Laboratorium Agrobioteknologi, Laboratorium Penelitian dan lahan percobaan Fakultas Pertanian, Universitas Muhammadiyah Yogyakarta pada bulan September 2015 hingga Juni 2016. Penelitian menggunakan rancangan percobaan faktorial (4 × 3) yang disusun dalam Rancangan Acak Lengkap (RAL) dengan media tanam pasir pantai. Faktor pertama adalah perlakuan inokulum yang terdiri dari 4 macam yaitu (1) Rhizobiumsp.-Mikoriza, (2) Rhizobiumsp.-Rhizobacteri indigenous Merapi, (3) Rhizobiumsp.-Mikoriza-Rhizobacteri indigenous Merapi dan (4) tanpa inokulum. Faktor kedua adalah kultivar kedelai yang terdiri dari 3 varietas yaitu (1) Grobogan, (2) Detam-1 dan (3) Petek. Pengamatan dilakukan terhadap aktivitas nodulasi, pengaruh mikoriza, dinamika populasi Rhizobacteri, pertumbuhan perakaran, pertumbuhan vegetatif, dan hasil. Hasil penelitian menunjukkan bahwa inokulasi Rhizobium sp. - mikoriza hanya berpengaruh terhadap diameter nodul dan inokulasi Rhizobium sp.-mikoriza pada varietas Petek nyata meningkatkan pertumbuhan perakaran, luas daun dan hasil biji (5,97 ton/h).

Kata kunci: Varietas kedelai, Rhizobium sp., Mikoriza, Rhizobacteria indigenous Merapi, Lahan pasir pantai
\end{abstract}

\section{INTRODUCTION}

Soybean has an important role as a protein source (Rahmat and Yuyun, 1996). Central Bureau of Statistics (Badan Pusat Statistik) [2015] stated that soybean production decreased by $5,38 \%$ yearly during the period of 2009 until 2013. Production of soybean was 850.000 tonnes in 2012, but soybean demand was forecasted to be 2.4 million tonnes. It was suggested that demand for tempeh and tofu reach 1.6 million tonnes and black soybean for soy sauce about
650,000 ton (Aditama, 2011). These figures suggest that, to catch up with the demand, soybean production needs to be increased by about 1.55 million tonnes.

Intensification such as high-yielding cultivars and biological fertilizer may provide ways to increase soybean production. Several soybean cultivars, such as Grobogan contains high protein and also high-yielding (Erliana et al., 2009), while local cultivar from Boyolali, Petek, is known as 
drought resistant cultivar, and Detam-1 cultivar contains high protein (45.36\%) as well as highyielding (3.45 tonnes/ha, [Balitkabi, 2008]).

Extensification may conducted by using marginal area (Arie, 2013), such as coastal area which has the potential use of $1.060 .000 \mathrm{ha}$. One of the drawback of coastal area is that it has low fertility, low nutrient and high porosity. Application of biological fertilizer may provide the alternative way to resolve coastal sandy soil problem. Some microorganisms are known to improve soil fertility such as Rhizobium sp., mycorrhiza and several indigenous Rhizobacteria such as Merapiindigenous Rhizobacteria. Rhizobium sp. is known to reserve Nitrogen, while mycorrhiza reserve Phosphor, and an indigenous Rhizobacteria, Merapi-indigenous Rhizobacteria, has been demonstrated to improve plant resistance to drought (Gunawan, 2014; Muhammad et al., 2014).

Double inoculation of soybean with Rhizobium sp. and mycorrhiza resulted in the increase of nitrogen on coastal sandy soil and kept humidity of rhizosphere (Gunawan, 2014). On the other hand, single inoculation using Rhizobium sp. did not increase plant dry weight and leaf area yet (Lilik, 2005). Previous study also demonstrated that double inoculation using Rhizobium sp. and mycorrhiza, and single inoculation using only Rhizobium sp. resulted not significantly different effect on the number of pod, grain weight and yield. Double inoculation of soybean using Rhizobium sp.-mycorrhiza cultivated on coastal sandy soil produced only $25 \%$ of yield potential. Similarly, osmotolerant Rhizobacteria-Rhizobium sp. association did not increase soybean growth and yield (Ngadiman et al., 2014). It is anticipated that inoculation of Grobogan cultivar using Rhizobium sp.-mycorrhiza - Merapi-indigenous Rhizobacteria, cultivated on coastal sandy soil, will increase soybean growth and yield which.
This study was, therefore, conducted to examine the contribution of inoculum association between Rhizobium sp., mycorrhizae and Merapiindigenous Rhizobacteria on the growth and yield of 3 soybean cultivars, and to determine the best inoculum and cultivars for soybean cultivation on coastal sandy soil.

\section{MATERIALS AND METHODS}

Materials used in this study were Rhizobium sp., Merapi-indigenous Rhizobacteria MB and MD isolates (Agung_Astuti, 2012 personal communication), crude inoculum of mycorrhiza, Grobogan, Petek and Detam-1 soybean cultivars. The study was conducted in the Agro-biotechnology Research Laboratory and experimental station of Faculty of Agriculture, Universitas Muhammadiyah Yogyakarta during the period of September 2015 to June 2016.

Experiments were conducted by using coastal sandy soil as planting medium in polybags, arranged in completely randomized design (CRD) of $4 \times 3$ factorial experiments and placed under the field condition. The first factor used was inoculation treatment consisted of 4 combinations of inoculum: (1) Rhizobium sp. - Mycorrhiza, (2) Rhizobium sp. - Merapi-indigenous Rhizobacteria, (3) Rhizobium sp. - Mycorrhiza - Merapi-indigenous Rhizobacteria, and (4) without inoculation. The second factor was soybean cultivars consisted of 3 varieties: (1) Grobogan, (2) Detam-1, and (3) Petek. Observation was carried out on nodulation, mycorrhizal effect, Rhizobacterial population dynamics, plant growth and yield.

The final results were analysed using ANOVA (analysis of variance) with $\alpha$ of $5 \%$. The significantly different treatment was further tested by Duncan's multiple range test (Duncan Multiple). Periodic observation data were presented on graphs and histograms. 


\section{RESULTS AND DISCUSSION}

The Effect of treatment on root nodulations

Rhizobium sp. infection is indicated by the formation of root nodule which indicates the compatibility with the plant. Table 1 shows the average number of nodules parameter presented following inoculation.

Table 1. Average number of nodule, nodule effectiveness, nodule weight and diameter in the ninth week

\begin{tabular}{lcccc}
\hline \multicolumn{1}{c}{ Treatment } & $\begin{array}{c}\text { Number of } \\
\text { nodule }\end{array}$ & $\begin{array}{c}\text { Effective nodule } \\
\text { percentage } \\
(\%)^{* * *}\end{array}$ & $\begin{array}{c}\text { Weight } \\
\text { of nodule } \\
(\mathrm{g})^{*}\end{array}$ & $\begin{array}{c}\text { Diameter } \\
\text { of nodule } \\
(\mathrm{mm})^{*}\end{array}$ \\
\hline Inoculum: & & & & \\
Rhizobium sp.- mycorrhiza & $8,76 \mathrm{a}$ & $65,42 \mathrm{a}$ & $0,38 \mathrm{a}$ & $3,74 \mathrm{a}$ \\
$\begin{array}{l}\text { Rhizobium sp.-Rhizobacteria } \\
\text { Rhizobium sp.- mycorrhiza- }\end{array}$ & $2,78 \mathrm{a}$ & $37,78 \mathrm{a}$ & $0,05 \mathrm{~b}$ & $1,59 \mathrm{a}$ \\
$\begin{array}{l}\text { Rhizobacteria } \\
\text { Without inoculum }\end{array}$ & $2,56 \mathrm{a}$ & $49,17 \mathrm{a}$ & $0,12 \mathrm{~b}$ & $2,46 \mathrm{a}$ \\
Soybean cultivar: & $1,78 \mathrm{a}$ & $20,83 \mathrm{a}$ & $0,15 \mathrm{~b}$ & $1,22 \mathrm{a}$ \\
Grobogan & & & & \\
Detam-1 & $6,42 \mathrm{p}$ & $49,17 \mathrm{p}$ & $0,31 \mathrm{p}$ & $2,86 \mathrm{p}$ \\
Petek & $4,08 \mathrm{p}$ & $31,11 \mathrm{p}$ & $0,14 \mathrm{p}$ & $1,72 \mathrm{p}$ \\
\hline \multicolumn{1}{c}{ Interaction } & $1,33 \mathrm{p}$ & $49,62 \mathrm{p}$ & $0,08 \mathrm{p}$ & $2,18 \mathrm{p}$ \\
\hline
\end{tabular}

Note: numbers followed by the same letter showed no significant difference based on the $F$ test $\alpha 5 \%$ and DMRT

(-) No interaction between treatments

$(-)$
$*$ square root data transformation

$*$ square root data transformation
$* * *$
arc-sin and square root data transformation

It was observed that soybean cultivar did not significantly affect nodulation as Rhizobium sp. was found effectively nodulated all soybean cultivar. Soybean cultivar which was inoculated by Rhizobium sp.-mycorrhiza showed significantly different number of nodule (Lilik, 2005; Yudhy and Inoriah, 2009). Ayu et al. (2013) suggested that the formation of nodule and nodule activity were influenced by phosphor from the mycorrhiza activities. The average of nodulation activities is presented in Table 1. It was the more effective nodule formed, the more nitrogen fixed and subsequently more chlorophyll and enzyme synthesised. The increase of chlorophyll and enzyme synthesis resulted in the increase of photosynthesis and vegetative, generative growth (yield) (Ramdana and Retno, 2015). Mycorrhiza is known to increase water availability in the rhizosphere, which will result in the effective nodule and increased weight of nodule (Nike-Triwahyuningsih, 2004). The result showed that the formation of nodule in coastal sandy soil was longer than in fertile soil. Mycorrhiza is also known to increase diameter and effectiveness of nodule. The larger nodule diameter, the higher nodule effectivity as the larger diameter gives indication that the development of Rhizobium sp. inside nodule is good. Small nodules indicate slow growing tissue bacteroid, which subsequently reduced the effectiveness of nitrogen fixation (Ramdana and Retno 2015).

\section{Effect of treatment on the efectivity of mycorrhizal inoculation}

The results of this study demonstrated that inoculum and cultivar treatment have the same effect on mycorrhizal-infected root percentage. Rhizobium sp.-mycorrhiza association, however, demonstrated higher mycorrhizal-infected root percentage during 9 week. Rhizobium sp. produces Nod Factor as growth regulator for mycorrhiza, therefore Nod factor induces colonization and development of mycorrhiza through nod gen induction (van Brussel et al., 1986 cit Xie et al.,1995). Table 2 showed the number of spores as the indicator of mycorrhizal growth, while the average of mycorrhizal-infected root percentage is presented in Table 3.

Table 2. Average number of mycorrhizal spore (spore/ $\mathrm{ml}) \times 104$ in the ninth week

\begin{tabular}{lcrrrrr}
\hline Treatment & $\begin{array}{c}\text { Rhizobium sp.- } \\
\text { mycorrhiza }\end{array}$ & $\begin{array}{c}\text { Rhizobium sp.- } \\
\text { Rhizobacteria }\end{array}$ & $\begin{array}{r}\text { Rhizobium sp.- } \\
\text { mycorrhiza- } \\
\text { Rhizobacteria }\end{array}$ & $\begin{array}{c}\text { Without } \\
\text { inoculum }\end{array}$ & Average \\
\hline Grobogan & $616,67 \mathrm{a}$ & $166,67 \mathrm{~cd}$ & $283,33 \mathrm{bc}$ & $533,33 \mathrm{a}$ & 400,00 \\
Detam-1 & $66,67 \mathrm{~d}$ & $358,33 \mathrm{~b}$ & $275,00 \mathrm{bc}$ & $616,67 \mathrm{a}$ & 329,17 \\
Petek & $233,33 \mathrm{bc}$ & $375,00 \mathrm{~b}$ & $166,67 \mathrm{~cd}$ & $325,00 \mathrm{~b}$ & 275,00 \\
\hline Average & 305,56 & 300,00 & 241,67 & 491,67 & $(+)$ \\
\hline
\end{tabular}

Notes: numbers followed by the same letter showed no significant difference based on the $F$ test $\alpha 5 \%$ and DMRT

$(+)$ There was interaction between treatments 
Table 3. Average of mycorrhizal-infected root percentage in the ninth week

\begin{tabular}{lc}
\hline Treatment & Mycorrhiza infection percentage $(\%)^{* *}$ \\
\hline Inoculum: & \\
Rhizobium sp.- mycorrhiza & $98,89 \mathrm{a}$ \\
Rhizobium sp.-Rhizobacteria & $95,56 \mathrm{a}$ \\
Rhizobium sp.- mycorrhiza-Rhizobacteria & $97,78 \mathrm{a}$ \\
Without inoculum & $94,44 \mathrm{a}$ \\
Soybean cultivar: & \\
Grobogan & $95,00 \mathrm{p}$ \\
Detam-1 & $97,50 \mathrm{p}$ \\
Petek & $97,50 \mathrm{p}$ \\
\hline Interaction & $(-)$ \\
\hline Notes: numbers followed by the same letter showed that no significantly difference based \\
on the F test a 5\% and DMRT. \\
$\begin{array}{l}-(-) \\
* * \\
* \text { arc-sin dacta transformation }\end{array}$
\end{tabular}

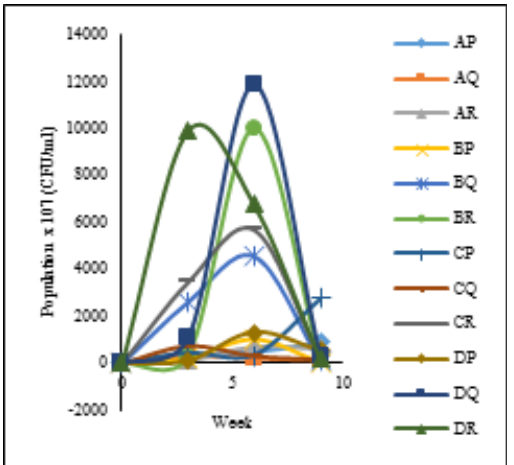

(a)

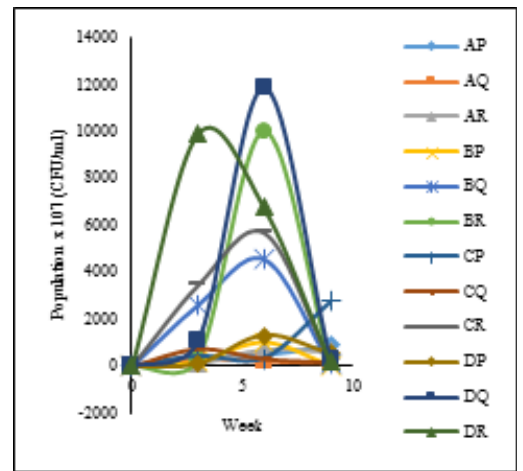

(c)
The different root exudates of each cultivar may contribute to the difference of microorganisms thrive in the rhizosphere, which may also affect the mycorrhizal growth. The presence of microorganism compatible with each cultivar may also increase plant growth. It was suggested that the factors which affect plant host may also affect to mycorrhizal growth (Tutik et al., 2016).

The effect of treatmet on activity of Merapi-indigenous Rhizobacteria

After inoculation was observed Merapi-indigenous Rhizobacteria population dynamics population. Microbial population dynamics for 9 weeks was presented in Figure 1.

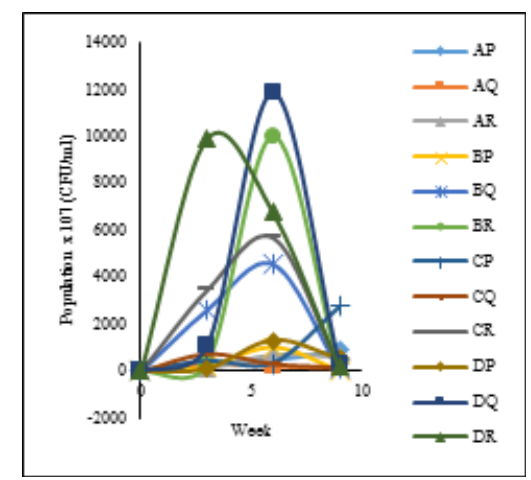

(b)

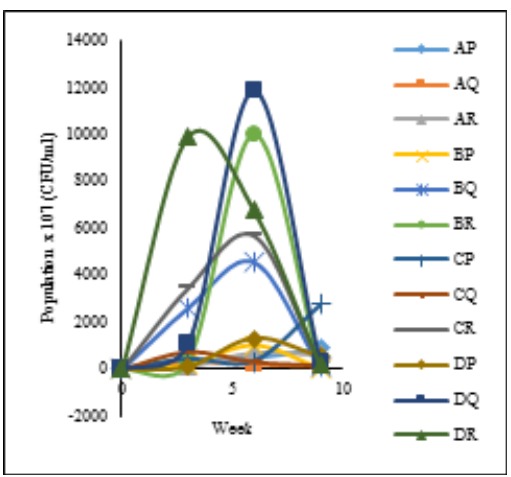

(d)

Figure 1. Population dynamics: (a) total bacteria, (b) other bacteria, (c) Merapi indigenous Rhizobacteria, MB isolate and (d) Merapi indigenous Rhizobacteria, MD isolate on three soybean cultivars

Remark:

$A=$ Rhizobium sp.-mycorrhiza

$\mathrm{B}=$ Rhizobium sp.-Rhizobacteria

$\mathrm{C}=$ Rhizobium sp.-mycorrhiza Rhizobacteria

$D=$ Without inoculum

$P=$ Grobogan

$Q=$ Detam -1

$\mathrm{R}=$ Petek 
Figure 1 showed that group of Rhizobacteria which compatible to each cultivar. MB and MD isolates in combination with mycorrhiza and Rhizobium sp. demonstrated the ability to adapt well as evidenced by the increase of population in the sixth week. Figure 1 (c) showed that Grobogan cultivar inoculated with MB isolate in combination with Rhizobium sp-mycorrhiza demonstrated good adaption as shown by entering the log phase in the $0-3^{\text {rd }}$ week,-while other treatment still in the adaptation phase. On the other hand, the population of MD isolate (Figure 1.d) on all of treatment showed tendency to decrease, with the exception of Detam-1 cultivar inoculated with Rhizobium sp.-mycorrhizaRhizobacteria that the Rhizobacteria reached the highest level of log phase until the sixth week, and reached the death phase after nine weeks. It was also observed that inoculation with mycorrhiza increased the Merapi-indigenous Rhizobacteria growth. Marcia et al. (2011) suggested that the positive effect of one microbe to another is attributed by the metabolite secretion.

\section{Root proliferation of three soybean cultivars culti-} vated on coastal sandy soil

Root proliferation illustrates the spread of the roots on the media. It was observed that inoculum and cultivar treatments resulted in a similar effect on root proliferation due to the presence of indigenous mycorrhizal spore and the facts that all treatments were infected by mycorrhiza including treatment without inoculum. Mycorrhiza-legumes association may increase the availability of phosphor, as well as the increase of nitrogenase activity which promoted root proliferation (Sylvia et al., 2005).

Root system is influenced by both genetic factors and growth media. Most of soil nutrients are absorbed from soil solution through the root. It was found that inoculum and cultivar treatments showed interacting effect on root length. The uinoculated Detam-1 cultivar showed tendency to have longer root as mycorrhiza-legume association may increase root proliferation (Sylvia et al., 2005). The average length of root, fresh and dry weight of root are presented in Table 4.

Table 4. Average length of root, fresh and dry weight of root after nine weeks

\begin{tabular}{lccc}
\hline \multicolumn{1}{c}{ Treatment } & $\begin{array}{c}\text { Length of } \\
\text { root (cm) }\end{array}$ & $\begin{array}{c}\text { Fresh root } \\
\text { weight (g) }\end{array}$ & $\begin{array}{c}\text { Dry root } \\
\text { weight (g) }\end{array}$ \\
\hline Grobogan-Rhizobium sp.- mycorrhiza & $60,83 \mathrm{ab}$ & $15,90 \mathrm{bcde}$ & $2,08 \mathrm{bcde}$ \\
Grobogan-Rhizobium sp.-Rhizobacteria & $40,83 \mathrm{bc}$ & $10,08 \mathrm{e}$ & $1,48 \mathrm{de}$ \\
$\begin{array}{l}\text { Grobogan-Rhizobium sp.- mycorrhiza } \\
\text {-Rhizobacteria }\end{array}$ & $55,00 \mathrm{abc}$ & $11,12 \mathrm{e}$ & $1,33 \mathrm{de}$ \\
Grobogan-without inoculum & $54,83 \mathrm{abc}$ & $12,11 \mathrm{de}$ & $1,12 \mathrm{e}$ \\
Detam-1-Rhizobium sp.- mycorrhiza & $59,00 \mathrm{abc}$ & $21,65 \mathrm{ab}$ & $2,22 \mathrm{bcde}$ \\
Detam-1-Rhizobium sp.-Rhizobacteria & $59,33 \mathrm{abc}$ & $11,31 \mathrm{e}$ & $1,68 \mathrm{cde}$ \\
$\begin{array}{l}\text { Detam-1-Rhizobium sp.- mycorrhiza } \\
\text {-Rhizobacteria }\end{array}$ & $66,30 \mathrm{a}$ & $23,88 \mathrm{ab}$ & $2,80 \mathrm{bc}$ \\
Detam-1- without inoculum & $72,17 \mathrm{a}$ & $19,82 \mathrm{abcd}$ & $2,38 \mathrm{bcd}$ \\
Petek- Rhizobium sp.- mycorrhiza & $67,67 \mathrm{a}$ & $24,47 \mathrm{a}$ & $4,13 \mathrm{a}$ \\
Petek- Rhizobium sp.-Rhizobacteria & $65,67 \mathrm{a}$ & $21,05 \mathrm{abc}$ & $2,39 \mathrm{bcd}$ \\
$\begin{array}{l}\text { Petek- } \text { Rhizobium sp.- mycorrhiza } \\
\text {-Rhizobacteria }\end{array}$ & $43,50 \mathrm{bc}$ & $12,81 \mathrm{cde}$ & $1,83 \mathrm{bcde}$ \\
Petek- without inoculum & $57,67 \mathrm{abc}$ & $18,37 \mathrm{abcde}$ & $2,96 \mathrm{~b}$ \\
\hline \multicolumn{1}{c}{ Interaction } & $(+)$ & $(+)$ & $(+)$ \\
\hline
\end{tabular}

Notes: numbers followed by the same letter showed that no significantly difference based on the $\mathrm{F}$ test $\alpha 5 \%$ and DMRT.

$(+)$ There was interaction between treatments

Rhizobium sp.-mycorrhiza-Petek interaction resulted in nutrient absorption and high photosynthesis accumulation on the root, which increased fresh and dry roots. Such increased was supported by the high number of leaf and leaf area on Petek. It was suggested that factors affecting photosynthesis were genetic and the absorption of nutrients from soil (Gardner et al., 1991).

Vegetative growth of three soybean cultivars cultivated on Coastal Sandy Soil

Table 6 lists growth parameter analysed. It is demonstrated that almost all growth parameters were affected by cultivar except fresh and dry 
canopy weight. Several studies also suggest that cultivar affects plant height (Wayan et al., 2011; Rosi and Santi, 2012), number of leaf (Wayan et. al., 2011) and flowering date (Anna, 2015; Rosi and Santi, 2012). Suhartina (2005) showed that Detam-1 height was higher than Grobogan and Petek suggesting that every cultivar brings out different character. Every cultivar has different ability to absorb nutrients resulting in different number of leaf and leaf area (Yutono, 1988 in:Farida, 2004). Gardner et al. (1991) also suggested that every cultivar showed different photosynthetic rates, while flowering date is affected by genetic factors, length of days and temperature (Suyamto and Musalamah, 2010).

Table 5. Average plant height, number of leaf, fresh and dry canopy weight, after nine weeks and the flowering date

\begin{tabular}{lccccc}
\hline \multicolumn{1}{c}{ Treatment } & $\begin{array}{c}\text { Plant } \\
\text { height } \\
(\mathrm{cm})\end{array}$ & $\begin{array}{c}\text { Number } \\
\text { of leaf }\end{array}$ & $\begin{array}{c}\text { Fresh } \\
\text { canopy } \\
\text { weight } \\
(\mathrm{g})^{*}\end{array}$ & $\begin{array}{c}\text { Dry } \\
\text { canopy } \\
\text { weight } \\
(\mathrm{g})^{*}\end{array}$ & $\begin{array}{c}\text { Flowering } \\
\text { date }\end{array}$ \\
\hline Inoculum: & & & & & \\
Rhizobium sp.- mycorrhiza & $45,51 \mathrm{a}$ & $35,31 \mathrm{a}$ & $66,97 \mathrm{a}$ & $14,83 \mathrm{a}$ & $33,30 \mathrm{a}$ \\
Rhizobium sp.-Rhizobacteria & $43,34 \mathrm{a}$ & $22,56 \mathrm{a}$ & $49,02 \mathrm{a}$ & $10,27 \mathrm{a}$ & $35,89 \mathrm{a}$ \\
Rhizobium sp.- mycorrhiza- & $41,64 \mathrm{a}$ & $23,19 \mathrm{a}$ & $47,87 \mathrm{a}$ & $10,15 \mathrm{a}$ & $35,81 \mathrm{a}$ \\
Rhizobacteria & $42,31 \mathrm{a}$ & $31,33 \mathrm{a}$ & $68,23 \mathrm{a}$ & $15,34 \mathrm{a}$ & $35,11 \mathrm{a}$ \\
Without inoculum & & & & & \\
Soybean cultivar: & $36,38 \mathrm{q}$ & $15,86 \mathrm{q}$ & $44,90 \mathrm{p}$ & $10,84 \mathrm{p}$ & $28,92 \mathrm{r}$ \\
Grobogan & $46,58 \mathrm{p}$ & $26,88 \mathrm{q}$ & $56,33 \mathrm{p}$ & $11,01 \mathrm{p}$ & $33,11 \mathrm{q}$ \\
Detam-1 & $46,64 \mathrm{p}$ & $41,56 \mathrm{p}$ & $72,84 \mathrm{p}$ & $16,08 \mathrm{p}$ & $46,06 \mathrm{p}$ \\
\hline Petek & $(-)$ & $(-)$ & $(-)$ & $(-)$ & $(-)$ \\
\hline \multicolumn{1}{c}{ Interaction } & & & & & \\
\hline
\end{tabular}

Note: numbers followed by the same letter showed no significant difference based on the $F$ test $\alpha 5 \%$ and DMRT.

$(-)$ No interaction between treatments

square root data transformation

Leaf area was found affected by cultivar and inoculum. Average leaf area in the ninth week is presented in Table 7. Petek, in combination with Rhizobium sp.-mycorrhiza resulted in significantly higher leaf area. Every cultivar has different ability to absorb nutrients resulting in different leaf area (Yutono, 1988 in: Farida, 2004), while the inoculum increased nutrient availability (note: there is no data supporting this notion). Mycorrhiza inoculation on soybean cultivated on coastal sandy soil increased nitrogen and kept the humidity surrounding the rhizosphere (Gunawan, 2014).

Table 6. Average leaf area in the ninth week $\left(\mathrm{cm}^{2}\right)^{\star}$

\begin{tabular}{cccccc}
\hline Treatment & $\begin{array}{c}\text { Rhizobium sp.- } \\
\text { mycorrhiza }\end{array}$ & $\begin{array}{c}\text { Rhizobium sp.- } \\
\text { Rhizobacteria }\end{array}$ & $\begin{array}{r}\text { Rhizobium sp.- } \\
\text { mycorrhiza- } \\
\text { Rhizobacteria }\end{array}$ & $\begin{array}{r}\text { Without } \\
\text { inoculum }\end{array}$ & Average \\
\hline Grobogan & $744,00 \mathrm{~d}$ & $699,33 \mathrm{~d}$ & $720,33 \mathrm{~d}$ & $465,33 \mathrm{~d}$ & 657,25 \\
Detam-1 & $837,00 \mathrm{~cd}$ & $1347,00 \mathrm{bcd}$ & $854,33 \mathrm{~cd}$ & $1938,67 \mathrm{abc}$ & 1244,25 \\
Petek & $2779,67 \mathrm{a}$ & $1066,67 \mathrm{~cd}$ & $1190,33 \mathrm{~cd}$ & $2383,33 \mathrm{ab}$ & 1855,00 \\
\hline Average & 1453,56 & 1037,67 & 921,67 & 1595,78 & $(+)$ \\
\hline
\end{tabular}

Notes: numbers followed by the same letter showed no significant difference based on the F test $\alpha 5 \%$ and DMRT.

$(-)$ No interaction between treatments

square root data transformation

Yield Components of Three Cultivars Soybean Cultivated on Coastal Sandy Soil

The productivity of plant was the ultimate goal of cultivation, including the cultivation of soybeans. Table 7 shows the average soybean yield components.

Table 7. Average number of pod, filled-pod percentage, pod dry weight and weight of 100 grains

\begin{tabular}{|c|c|c|c|c|}
\hline Treatment & $\begin{array}{l}\text { Number } \\
\text { of pod* }\end{array}$ & $\begin{array}{l}\text { Filled-pod } \\
\text { percentage } \\
(\%)^{*}\end{array}$ & $\begin{array}{l}\text { Pod dry } \\
\text { weight } \\
\text { (gram)* }\end{array}$ & $\begin{array}{c}\text { Weigh of } \\
100 \text { grains } \\
\text { (gram) }\end{array}$ \\
\hline \multicolumn{5}{|l|}{ Inoculum: } \\
\hline Rhizobium sp.- mycorrhiza & $128,83 \mathrm{a}$ & $24,93 \mathrm{a}$ & $11,64 a$ & $4,75 \mathrm{a}$ \\
\hline Rhizobium sp.-Rhizobacteria & $142,75 a$ & $26,97 \mathrm{a}$ & $12,59 a$ & $5,19 a$ \\
\hline $\begin{array}{l}\text { Rhizobium sp.- mycorrhiza- } \\
\text { Rhizobacteria }\end{array}$ & $115,50 \mathrm{a}$ & $15,51 \mathrm{a}$ & $10,94 a$ & $4,57 \mathrm{a}$ \\
\hline Without inoculum & $128,44 \mathrm{a}$ & $18,49 a$ & $10,14 a$ & $4,51 \mathrm{a}$ \\
\hline \multicolumn{5}{|l|}{ Soybean cultivar: } \\
\hline Grobogan & $45,62 \mathrm{r}$ & $6,72 q$ & $7,06 r$ & $5,51 p$ \\
\hline Detam-1 & $127,40 \mathrm{q}$ & $19,27 \mathrm{pq}$ & $15,78 p$ & $4,49 p$ \\
\hline Petek & $213,63 p$ & $38,43 p$ & $11,14 q$ & $4,26 p$ \\
\hline Interaction & $(-)$ & $(-)$ & $(-)$ & $(-)$ \\
\hline
\end{tabular}

Note: numbers followed by the same letter showed no significant difference based on the $F$ test $\alpha 5 \%$ and DMRT.

(-) No interaction between treatments

square root data transformation

Cultivar was found to affect the number of total pods (Yudhy and Inoriah, 2009), filled-pod percentage and pod dry weight. Rhizobium sp.- 
Rhizobacteria association also showed tendency to have the best result on number of pod, pod dry weight, grain weight and weight of 100 grains. Some of PGPR bacteria have been demonstrated to develop association which resulted in the increase of nodulation and nitrogen absorption of legume (Figueiredo et al., 2011. Petek was the cultivar with the highest number of pod and filledpod percentage, while Detam-1 and Grobogan were the cultivars with highest pod dry weight, and the highest weight of 100 grains, respectively.

Table 8. Average grain weight and yield

\begin{tabular}{lcc}
\hline \multicolumn{1}{c}{ Treatment } & Grain weight $(\mathrm{g})^{*}$ & Yield (ton/ha)* \\
\hline Grobogan-Rhizobium sp.- mycorrhiza & $0,74 \mathrm{~b}$ & $0,33 \mathrm{~b}$ \\
Grobogan-Rhizobium sp.-Rhizobacteria & $2,01 \mathrm{~b}$ & $0,89 \mathrm{~b}$ \\
$\begin{array}{l}\text { Grobogan-Rhizobium sp.- mycorrhiza } \\
\text {-Rhizobacteria }\end{array}$ & $1,86 \mathrm{~b}$ & $0,83 \mathrm{~b}$ \\
Grobogan-without inoculum & $0,44 \mathrm{~b}$ & $0,19 \mathrm{~b}$ \\
Detam-1-Rhizobium sp.- mycorrhiza & $1,26 \mathrm{~b}$ & $0,56 \mathrm{~b}$ \\
Detam-1-Rhizobium sp.-Rhizobacteria & $2,91 \mathrm{~b}$ & $1,29 \mathrm{~b}$ \\
$\begin{array}{l}\text { Detam-1-Rhizobium sp.- mycorrhiza } \\
\text {-Rhizobacteria }\end{array}$ & $1,41 \mathrm{~b}$ & $0,63 \mathrm{~b}$ \\
Detam-1- without inoculum & $2,95 \mathrm{~b}$ & $1,31 \mathrm{~b}$ \\
Petek- Rhizobium sp.- mycorrhiza & $13,43 \mathrm{a}$ & $5,97 \mathrm{a}$ \\
Petek- Rhizobium sp.-Rhizobacteria & $10,47 \mathrm{a}$ & $4,65 \mathrm{a}$ \\
$\begin{array}{l}\text { Petek- } \text { Rhizobium sp.- mycorrhiza -Rhi- } \\
\text { zobacteria }\end{array}$ & $2,91 \mathrm{~b}$ & $1,29 \mathrm{~b}$ \\
Petek- without inoculum & $4,41 \mathrm{~b}$ & $1,96 \mathrm{~b}$ \\
\hline \multicolumn{1}{c}{ Interaction } & $(+)$ & $(+)$ \\
\hline
\end{tabular}

Notes: numbers followed by the same letter showed that no significantly difference based on the $\mathrm{F}$ test $\alpha 5 \%$ and DMRT.

(-) No interaction between treatment

square root data transformation

Grain weight and yield on Petek in combination with Rhizobium sp.-mycorrhiza-Rhizobacteria were significantly higher than other treatments. Rhizobium sp.- mycorrhiza or Rhizobium sp.Rhizobacteria inoculation were better than third inoculation. It is known that grain weight and yield is supported by length root, root fresh and dry weight as a result of inoculation. The longer and the more complex roots, the greater so water and nutrient absorption (Lakitan, 2007). The availability of nutrients, combined with dif- ference number of leaves and leaf area of each cultivar required for photosynthesis, will affect the filling of seed which leads to the increase of grain weight and yield. It should also be noted that each cultivar has different adaptation to the environment (Yudhy and Inoriah, 2009), which means that Petek cultivar is more adaptive to coastal sandy soil as it is regarded as quite drought resistant cultivar (Sri et al., 2015).

\section{CONCLUSION}

The present study demonstrated that inoculation of Petek cultivar using Rhizobium sp.-mycorrhiza resulted in significantly increased root growth, leaf area, and yield (5.97 ton/ha) and diameter of nodule. Therefore, it is concluded that association between Rhizobium sp-mycorrhiza and Rhizobium sp.-Merapi-indigenous Rhizobacteria with Petek is suitable for soybean cultivation on coastal sandy soil.

\section{ACKNOWLEDGEMENTS}

The authors would like to thank PT. Indofood Sukses Makmur for providing research grants through Indofood Riset Nugraha 2015/2016 program.

\section{REFERENCES}

Adetama, D. S. 2011. Analisis Permintaan Kedelai. Fakultas Ekonomi Universitas Indonesia. Jakarta. 14 p.

Agung_Astuti. 2012. Isolasi Rhizobakteri indigenous Lahan Pasir Vulkanik Merapi yang Tahan Terhadap Cekaman Kekeringan. Scientific Seminar in Faculty Agriculture, UMY.

Anna E., Diana S. H. and Isman N. 2015. Respon Morfologis dan Fisiologis Beberapa Varietas Kedelai (Glycine max (L.) Merril) di Tanah Masam. Jurnal Online Agroekoteknologi. 3 (II): 507514.

Arie. 2013. Angan Swasembada Pangan. http://www.kompasiana.com/ariefebstyo/angan-swasembada-pangan_552995 c8f17e614a0ad623a8. Diakses 10 Juli 2015.

Ayu M., Rosmayanti dan Luthfi A. M. 2013. Pertumbuhan dan Produksi Beberapa Varietas Kedelai terhadap Inokulasi BradyRhizobium. Jurnal Online Agroteknologi. 1(2):15-23.

Balitkabi. 2008. Deskripsi Varietas Unggul Kacang-kacangan dan Umbi-umbian. Balai Penelitian Tanaman Kacang-kacangan dan Umbi-umbian, Malang.171 hal. 
BPS. 2015. Produksi Kedelai. http://BPS.go.id. Diakses 2 Juni 2015.

Erliana G, Sri S. A. dan Sri W. 2009. Varietas Unggul Kedelai Untuk Bahan Baku Industri Pangan. Jurnal Litbang Pertanian. 28 (3):79-87.

Farida K. 2004. Pengaruh Inokulasi Rhizobium - CMA terhadap Pertumbuhan dan Hasil Dua Varietas Kedelai pada Tanah Entisol. Skripsi Fakultas Pertanian UMY. Yogyakarta.

Figueiredo, M., Ademir S., Helio A. and Mario de A. 2011. Biodiversity and The Potential of PGPR: Plant-Microorganism Interactions in Microbial Ecology of Tropical Soils. Nova Science Publisher. Inc. New York. p.332.

Gardner, F. P., R. Brent P. dan Roger L. M. 1991. Fisiologi Tanaman Budidaya. Ul Press. Jakarta. 428 hal.

Gunawan B. 2014. Manajemen Sumberdaya Lahan. Lembaga Penelitian, Publikasi dan Pengabdian Masyarakat Universitas Muhammadiyah Yogyakarta. Yogyakarta. Hal. 147-160.

Lakitan, B. 2007. Dasar - Dasar Fisiologi Tumbuhan. PT. Raja Grafindo Persada. Jakarta

Lilik U. 2005. Pengaruh Inokulasi Rhizobium-VAM dan Bahan Organik Terhadap Pertumbuhan dan Hasil Tanaman Kedelai di Lahan Pasir Pantai. Jurnal Agr-UMY. XIII (1): 20-31.

Marcia F., Ademir S., Helio A and Mario A. 2011. Biodiversity and The Potential of PGPR: Plant-microorganism Interactions. Nova Scince Publisher, Inc. New York. p.332.

Muhamad H. R., Agung_Astuti dan Haryono. 2014. Pengujian Toleransi Terhadap Cekaman Kekeringan pada Berbagai Varietas Padi yang Diinokulasi Rhizobacteri indigenous Merapi. http://thesis.umy.ac.id/datapublik/t34775.pdf. Diakses 10 Juli 2015. Hal. 4-10.

Nasih W. Y. 2009. Membangun Kesuburan Tanah di Lahan Marginal. Jurnal IImu Tanah dan Lingkungan. IX (2):137-141.

Nike-Triwahyuningsih, Agung_Astuti, Lilik U., Bambang H. I., Budiyono dan F. Khusna. 2004. Aktivitas Nodulasi pada Kedelai Edamame dan Wilis pada Perlakuan Inokulasi Ganda Rhizobium-Cendawan Mikoriza Arbuskula di Tanah Entisol Berkapur. Jurnal AgrUMY XII (2):65-78.

Ngadiman, Sri W., Triwibowo Y. dan Marta R. T. 2014. Peranan Inokulasi Ganda Rhizobia Pemnodul Akar dan Rhizobacteri Osmotoleran terhadap Pertumbuhan Tanaman Kedelai dalam Kondisi Cekaman Kekeringan. http://opac.lib.ugm.ac.id/index. php?mod=penelitian_detail\&sub=PenelitianDetail\&act=view \&typ=html\&buku_id=428551\&obyek_id=4. Diakses 11 Juli 2015.

Rahmat R. dan Yuyun Y. 1996. Kedelai, Budidaya dan Pasca Panen. Kanisius. Yogyakarta. Hal. 12.

Ramdana S. dan Retno P. 2015. Rhizobium: Pemanfaatannya sebagai Bakteri Penambat Nitrogen. Info Teknis EBONI 12 (1):51-64

Rosi W. dan Santi D. A. 2012. Tanggap Beberapa Varietas Kedelai terhadap Pemberian Pupuk Organik Cair Bio P 2000Z. Prosiding Seminar Nasional. Purwokerto.

Sri S., Didik I., Putu S. dan Jaka W. 2015. Kebutuhan Air, Efisiensi Penggunaan Air dan Ketahanan Kekeringan Kultivar Kedelai. Agritech 35 (1):114-120.
Suhartina. 2005. Deskripsi Varietas Unggul Kacang-kacangan dan Umbi-umbian. Balai Penelitian Tanaman Kacang-kacangan dan Umbi-umbian. Malang. 154 hal.

Suyamto dan Musalamah. 2010. Kemampuan Berbunga, Tingkat Keguguran Bunga dan Potensi Hasil Beberapa Varietas Kedelai. Buletin Plasma Nutfah 16 (1):38-43.

Sylvia, David M., Jeffry J. M., Peter G. H. and David A. Z. 2005. Principles and Applictions of Soil Microbiology. Pearson Education Inc., Upper Saddle River. New Jersey. 640 p.

Tutik N., Kristanti I. P. dan Dini E. 2016. Isolasi Mikoriza Vesikular Arbuskular pada Lahan Kering di Jawa Timur. http://personal. its.ac.id/files/pub/5146-tutiknurhidayatissi-EDITING\%20 KE\%202\%20ISOLASI.doc. Diakses 18 Mei 2016.

Wayan W., Ari A. dan Nihla F. 2011. Respon Berbagai Varietas Kedelai (Glycine max (L.) Merril) terhadap Sterilisasi Tanah dan Inokulasi dengan Mikoriza Arbuskular. Agroteksos. 21 (I): 19-28.

Xie, Zhi-Ping, Christian S., Horst V., Andreas W., Said J., William J. B., Regina V. and Thomas B. 1995. Rhizobial Nodulation Factors Stimulate Mycorrhizal Colonization of Nodulating and Nonnodulating Soybeans. Plant Physiol. 108:1519-1525.

Yudhy H. B. dan E. Inoriah. 2009. Dampak Inokulasi Ganda Cendawan Mikoriza Arbuskula dan Rhizobium Indigenous pada Tiga Genotipe Kedelai di Tanah Ultisol. Akta Agrosia. 12(2):155-166. 